日臨外医会誌 $51(6), 1217-1221,1990$

症例

急激な経過で死の転帰をとった甲状腺平滑筋肉腫の 1 例

財団法人竹田綜合病院外科

川口吉 洋

福島県立医科大学第 2 外科（主任：阿部力哉教授）

金沢匡司 中山浩一 浦 住 幸治郎

竹 内 真 一 阿 部 力 哉

症例は, 72歳女性。呼吸困難で耳眊科通院加療中左甲状腺腫を指摘され当科入院した。 腫煌增大が急速で呼吸困難が強くなり気管切開を施行した。この時に腫瘍の一部す試験 切除し病理学的に検索した. H.E. 染色では未分化癌と考えられたが, 免疫組織学的な検 索を行った結果平滑筋肉尰と診断された，本症例は手術することなく死亡の転旲をとっ た. 甲状腺の平滑筋肉弫は，未分化癌一特に䊉錘細胞型との鑑別は困難であり，免度組 織染色による検索を早急に行って診断を決めることが必要である.

索引用語：甲状腺平滑筋肉腫，未分化癌，免疫組織染色

はじめに

甲状腺に発生する董湯の中で肉腫の頻度は極めて少 ない．臨床的な释過から甲状腺末分化癌と考えられた 症例が腫場の免疫組織学的所見から甲状腺の平滑筋肉 腫（以降本症と略す）と診断できた稀な症例を経験し たのでその臨床経過および組織学的診断について報告 ナる.

患者：72歳，女性.

\section{症例}

既往歴：43歳時子宮筋畽の手術.

家族歴：特記すべきことはない，

現病歴：1988年12月20日朝より息苦しい感じが出現 したため，某病院耳悬科を受診し急性咽頭炎と診断さ れたが, Epiglottis の発赤・腫脹が強く呼吸困難に陥る 危険があったことから直ちに福島医大耳鼻科を紹介さ れた。ここでの診察では Epiglottis の所見は同様では あるものの呼吸状態は前院で施行された吸入療法が効 を奏しすでに軽快していた。 そのためにしばらくこの 吸入療法を前院で続けていたが，同年12月23日再び息 苦しさが出現し，さらに左䫑下部腫脹も認められたた め頸部 CT 検查が行われた。 その結果，甲状腺と思わ れる部にリング状石灰化を伴ら異常陰影があり董掦の 疑いをるたれ，再度福島医大耳鼻科を紹介された。同
科受診時に息苦しさは消失し, Epiglottis の発赤・重脹 は軽度認められる程度となっていた。しかし，左頸部 に 2 個の弾性硬の腫湟を触知され，甲状腺シンチクラ ムの結果甲状腺癌が疑われた。1989年 2 月にはいり再 び呼吸困難が強くなってきたため第 2 外科に紹介さ れ，2月16日に入院した。

入院時現症: 身長 $140 \mathrm{~cm}$, 体重 $64 \mathrm{~kg}$, 血王 $148 / 98$ $\mathrm{mmHg}$, 脈拍 $90 /$ 分整, 顔面は浮腫状であり, 皮虚は㲦 蜗し光沢がない。眼䀫結膜に負血はなく眼球結膜に黄 疸も認めない。頸部、腋窝部および単径部の表在リン パ節は触知しない，聴診上両肺野に閉塞性ラ音を聴取 できた。呼吸は喘鳴が強くこれは体動時に増強された。 胸部 X-P 上両肺野の肺紋理増強之左第一弓と左第四 弓の突出を認めた。 心雑音はなかった。腹部は平坦で 肝・脾・腎は触知されなかった，四肢に浮庫はなかっ た。

甲状腺 (図 1)：甲状腺左葉に図 1に示すよ5に2 個 の弾性硬, 表面不整, 可動性不良な腫湯を触知した。 甲状腺右葉は触知されなかった。肥満体で，顔面・頸 部に浮連すあり, 詳細を知る触診は困難であった。

入院時梌查成綨（表 1)：白血球，LDH およびCEA などの軽度上昇をみとめた。ささらに総蛋白やへマトク リットの軽度上昇があり脱水傾向をらかがわせた。 甲 状腺ホルモンなどは正常範囲にあった。

$\mathbf{X}$ 線学的検查：顓部単純 X-P では, 頸部左側に石灰 


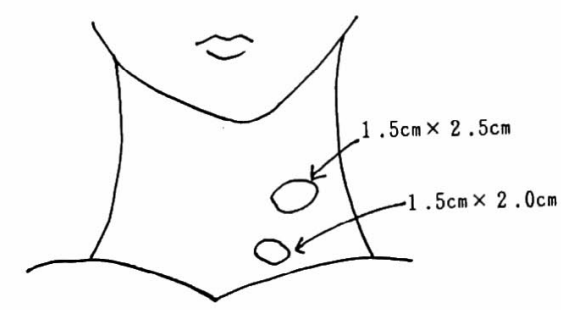

図 1 甲状腺：触診上 2 個の腫瘍が触知された.

\section{表 1 入院時一般検査}

\begin{tabular}{|c|c|c|c|}
\hline WBC & 9900 & $\mathrm{Na}$ & $135 \mathrm{mEq} / \mathrm{l}$ \\
\hline $\mathrm{RBC}$ & $\times 10^{4}$ & $\mathrm{~K}$ & 4.211 \\
\hline $\mathrm{Hb}$ & $15.7 \mathrm{~g} / \mathrm{dl}$ & $\mathrm{Cl}$ & $100 " /$ \\
\hline Hct & $45.2 \%$ & $\mathrm{Ca}$ & $5.2 \prime \prime$ \\
\hline APTT & 33.2 秒 & $\mathrm{P}$ & $3.2 " \prime$ \\
\hline 出血時間 & 2 分 & Total chole & $211 \mathrm{mg} / \mathrm{dl}$ \\
\hline Total protei & in $8.0 \mathrm{~g} / \mathrm{dl}$ & CEA & $7.3 \mathrm{mg} / \mathrm{dl}$ \\
\hline Alb & $4.5 \mathrm{~g} / \mathrm{dl}$ & $\mathrm{T}_{3}$ & $1.0 \mathrm{mg} / \mathrm{dl}$ \\
\hline $\mathrm{A} / \mathrm{G}$ & 1.3 & $\mathrm{~T}_{4}$ & $8.9 \mu \mathrm{g} / \mathrm{dl}$ \\
\hline GOT & $29 \mathrm{IU} / 1$ & TSH & $2.7 \mu \mathrm{U} / \mathrm{ml}$ \\
\hline GPT & $9 \mathrm{IU} / 1$ & \multicolumn{2}{|c|}{ Microsome $\mathrm{T} 100>$} \\
\hline LDH & $447 \mathrm{IU} / 1$ & Thyroid T & $100>$ \\
\hline $\mathrm{Al}-\mathrm{p}$ & $116 \mathrm{IU} / 1$ & \multicolumn{2}{|c|}{${ }_{123} \mathrm{I}$ up take $4.11 \%$} \\
\hline Total Bil & $1.3 \mathrm{mg} / \mathrm{dl}$ & CA19-9 & $59 \mathrm{U} / \mathrm{ml}$ \\
\hline Direct Bil & $0.3 \mathrm{mg} / \mathrm{dl}$ & SCC & $1.0 \mathrm{ng} / \mathrm{ml}$ 以下 \\
\hline TTT & $1.6 \mathrm{KU}$ & \multicolumn{2}{|c|}{ カルシト ニン $43 \mathrm{ng} / \mathrm{dl}$} \\
\hline ZTT & $13.3 \mathrm{KU}$ & PTH & $0.68 \mathrm{ng} / \mathrm{dl}$ \\
\hline
\end{tabular}

化陰影をみとめ, 気管の右方への偏位と狭窄がられ た。頸部 CT (写真 1 ) では，甲状腺左葉にリング状石 扊化を伴う腫瘍陰影がありその内部に低吸収域があっ た。また，左内頸静脈の閉塞がみられ腫瘍浸潤による 変化であることが推測された。 その外側にも同様に内 部の低吸収域を持つ腫湢が確認された。 CT 上では気 管の圧排狭窄の変化を認めるが，腫瘍による気管浸潤 所見は明瞭ではなかった。甲状腺右葉はほぼ正常であ り腫湯などの所見はなかった。

核医学検査： ${ }^{201} \mathrm{Tl}$ シンチグラム（写真 2）上では甲 状腺部への取り込みは左右共にび漫性にみとめら れ， ${ }^{123} I$ シンチグラム(写真 3 ) は左葉全体の集積低下 をみとめ, 両検査からは甲状腺左葉の悪性腫瘍がもっ とも考えられた。

臨床経過および治療：入院後呼吸困難が強くなった ため気管内挿管 (Portex 6.5) をし吸引を頻回に行っ たが，なかなか状態の改善はみられなかったため1989 年 2 月 20 日気管切開を施行した。 甲状軟骨下に皮膚切 開し前頸筋を分けて行くと甲状腺左葉から狭部にかけ

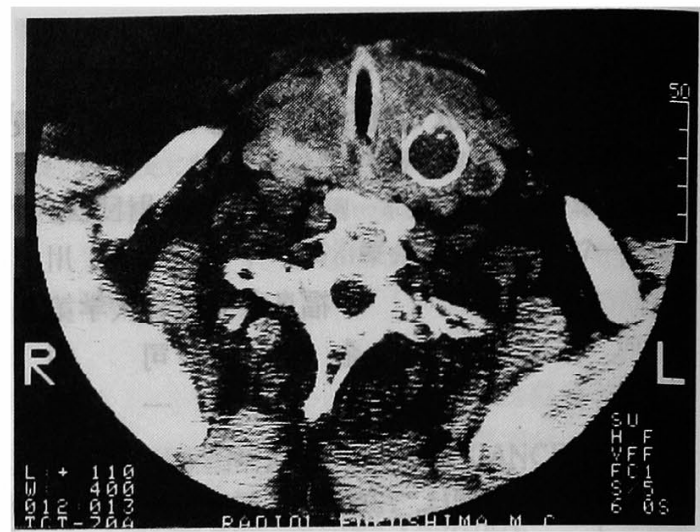

写真 1 頸部 CT：甲状腺左葉にリング状石灰化を伴 ら腫瘍とその外側にも内部に低吸収領域をもつ腫瘍 がみられる。

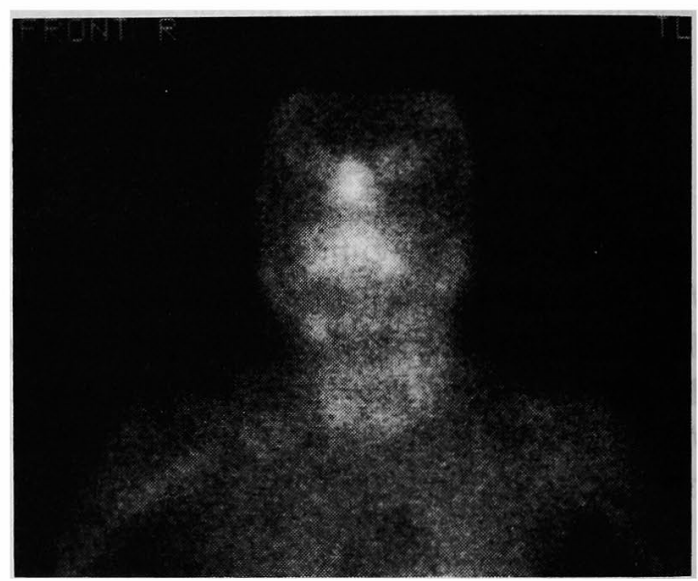

写真 $2{ }^{201} \mathrm{Tl}$ シンチグラム：ビ漫性に ${ }^{201} \mathrm{~T} 1$ の左右甲 状腺への取り込みがみとめられる。

て表面凹凸不整で境界鮮明な易出血性の腫瘍をみとめ 肉眼的に未分化癌が想定された。この腫瘍の一部を切 除し病理組織学的検索に供した。気管切開はこの腫瘍 を切離するように施行し, portex 9-0チューブを使用 したが，術中には腫瘍の気管浸潤の程度は確かめられ なかった。な押甲状腺右葉は正常であった．気管切開 後からかなりの喀痰が吸引され呼吸困難は軽减され た. 全身状態を考慮し，現時点での手術の適心はない と判断し中心静脈栄養下に, 3 月 8 日より $6 \mathrm{Mev}$ x-ray $2 \mathrm{~Gy} /$ 日の全頸部照射を開始とした。しかし，照射後に も腫瘍増大を示し, 胸部 X-P 上転移巣は明らかではな かったが, 胸水貯留, 肺炎を併発し 4 月16日死亡した. 死後の剖検はできなかった。 


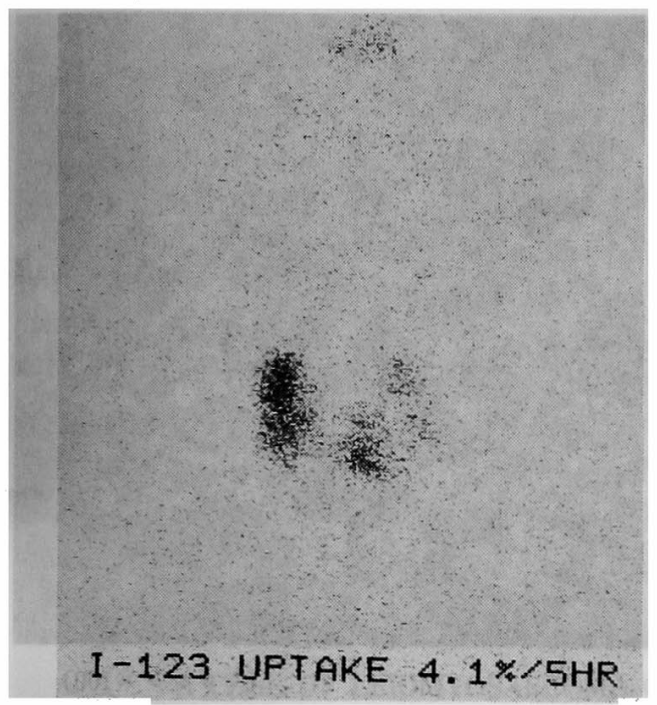

写真 $3{ }^{123}$ I シンチグラム：甲状腺左葉の集積低下を みとめる.

病理組織所見：気管切開施行時に腫瘍の一部を試験 切除し病理組織学的に検査した. H.E. 染色法では, 紡 錗形で異型度の強い細胞の渦巻状の密な増殖と多数の 核分裂像がみとめられた（写真 4 ）ので未分化癌の紡 錘細胞型と診断された。しかしながら，腫湯細胞の配 列が一様すぎて bizarreなものも認められないなどの 問題点があることから免疫組織染色を試みた。結果は ケラチン陰性, デスミン陽性, ミオシン陽性(写真 5) であったため本症例は最終的に平滑筋肉腫と診断され た.

\section{考 察}

甲状腺悪性腫瘍の中で肉腫の発生する頻度は少ない と言われている(12). Chesky ${ }^{3}$ によると真の甲状腺肉腫 は甲状腺畽晹の $0.6 \%$ そられたのみであり， Aldinger() は甲状腺癌 1,174 例中 3 例のみであったと 報告している。一方, Kind ${ }^{5}$ によると甲状腺腫場の $20 \%$ が肉腫であると報告しているか，これは腫瘍の組織分 類の困難さから出ており，その後 Hedinger $\left.{ }^{6}\right)$ にる追 跡調査ではそれらの症例の $97 \%$ は未分化癌であったと いら．このことより分化した甲状腺癌は H.E. 染色に よって腫瘍の組織分類が可能であるが，分化度の低い 尰瘍では病理組織学的な確定診断に困難を伴う。

近年, 病理学的に腫瘍細胞の起源を同定する手段之 して免疫組織染色法が広く応用されるようになっ $た^{7)}$. 本症に対する免疫組織染色法による鑑別診断法

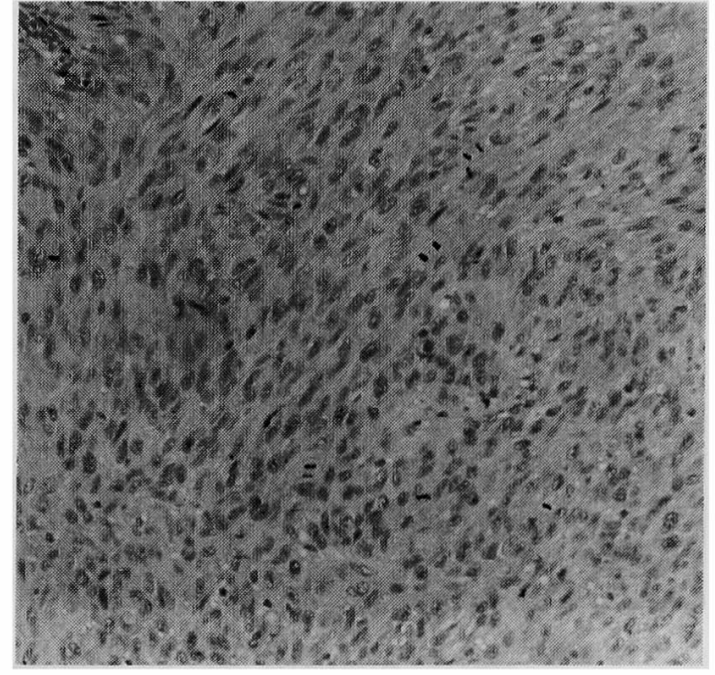

(H.E. 染色 $\times 33)$

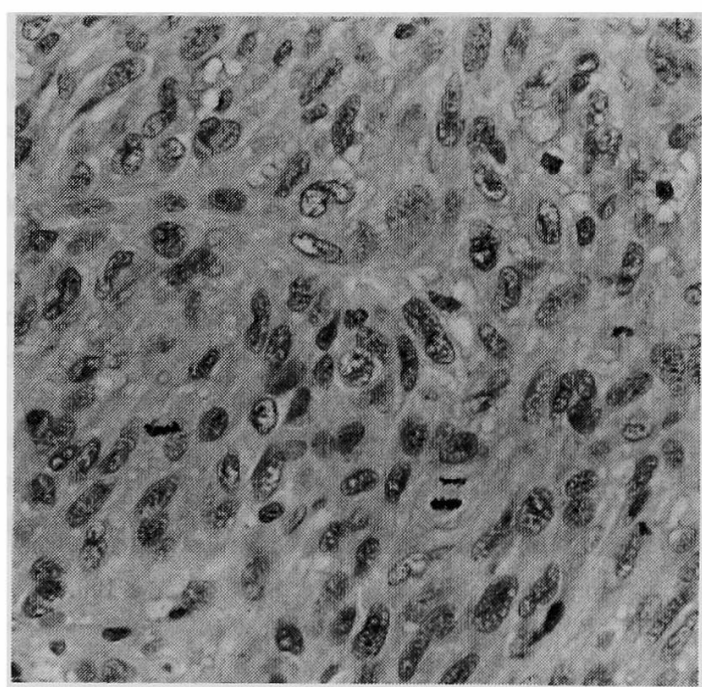

(H.E. 染色 $\times 80)$

写真 4 病理組織（H.E. 染色）：紡鍾細胞型の渦巻状 の増殖があり，その細胞には多数の核分裂像をみと める。

の第一段階としては，ケラチンとビメンチンを抗原と する染色があげられる。しかじメンチンはパラフィ ン包埋標本では染色が不完全とされ診断的価値はうす い.この第一段階での検索でケラチン陽性の場合は上 皮性腫場を，逆にヶラチン陰性腫瘍は非上皮性腫瘍を 考えなければならない，自験例はケラチン陰性であっ たことから未分化癌の診断は否定されたことになる. 次に第二段階の検索のための抗原として種々列举さ 


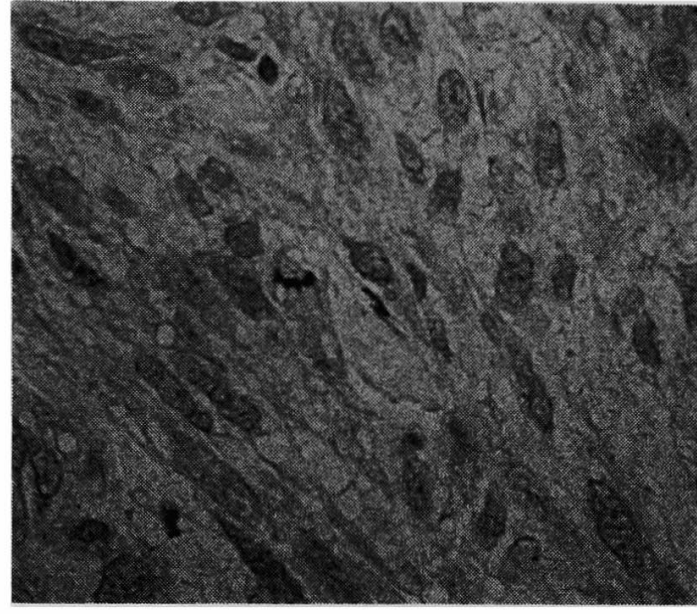

(ケラチン×100)

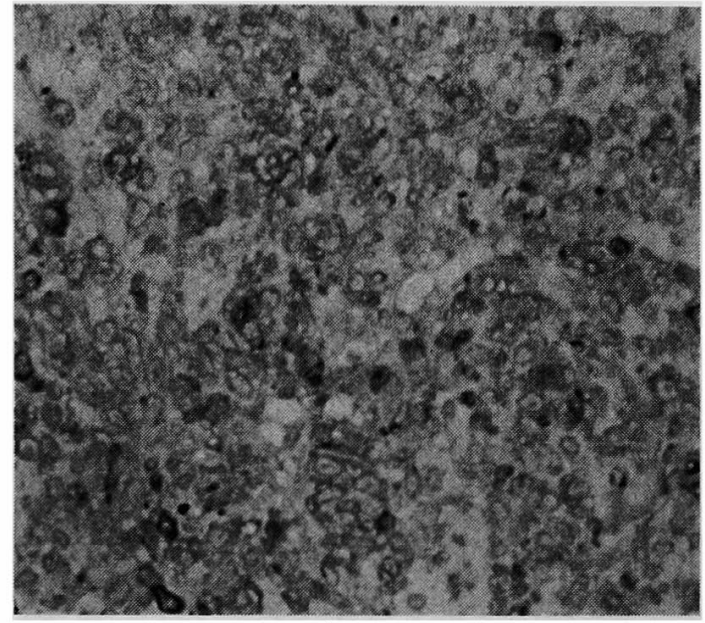

（デスミン×100）

れるが，自験例の紡錘細胞型を示す未分化癌類似の組 織構造を示寸腫場としては平滑筋肉腫が考えられるこ とから，デスミンおよびミオシンの検索を行った。デ スミンは従来筋肉腫場のマーカーとして使用され，ミ オシンは平滑筋由来の抗原とされている，自験例はデ スミン：オシンともに陽性であったことから最終的 には平滑筋肉腫と診断した。

本症の免疫組織学的検討をした Kawahara ${ }^{\mathrm{a}}$ は未分 化癌と鑑別診断にデスミンとケラチンの組み合わせを 重視し，ビメンチンは特に甲状腺の間葉系腫煌におい ては必ずしも良好なマーカーではないと述べている。 吉岡9も抗デスミン血清を用いた䤃素抗体法による染 色で本症と診断したことを報告している.

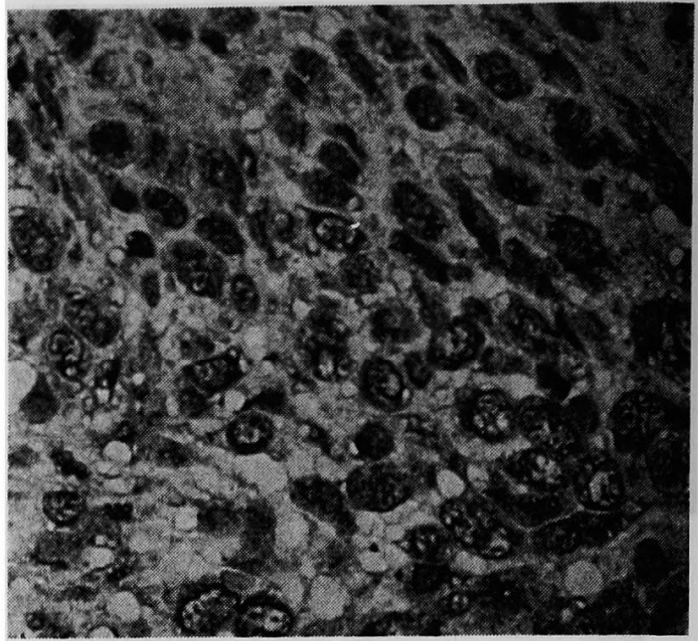

(ミオンン $\times 100)$

写真 5 免疫組織染色：ケラチンは陰性であるが，デ スミン・ミオシン陽性細胞をみとめる。

頻度の少ない甲状腺肉腫の中では, 主にみられるも のとして線維肉腫, 血管肉腫があげられるが, 本症の 報告は本邦拈よび欧米においても極めて稀であ $3^{8) \sim 10)}$.

さて, 本症の臨床経過について考察してみると, Kawahara' ${ }^{8}$ 扰よび吉 岡9"手術出来た症例を報告し それぞれの予後は術後 3 力月死亡および術後21力月生 存となっている。自験例は全身状態の低下から手術不 可能と判断し放射線療法を施行したが，開始後 1 力月 で急速に死の転帰をとった。 また本症に限らず他の甲 状腺肉腫についても線維芽肉腫では Chesky ${ }^{3}$ の報告 をみると 4 例中 3 例は術後 7 日から 1 カ月で死亡して いる。これらのことから甲状腺の肉腫は急速な経過を 採るものが多い㑯向が伺えるが, 吉岡9の報告や $\mathrm{Chesky}^{3)}$ の残りの 1 例の術後20年生存などから長期生 存の可能性も残している.

結 語

甲状腺に発生した極めて稀な平滑筋肉腫を経験した が，甲状腺末分化癌と考えられる症例ではその病理組 織学的な鑑別診断に免疫組織学的染色を行うことの必 要性が強く感じられた。

\section{文献}

1) Sidney HI, Lewis EB: The Thyroid JB, Lippincott Company, Philadelphia, 1371, 1986

2) Hedinger $\mathrm{C}:$ International Histological Classification of Tumors. Histological Typing 
of Thyroid Tumors. 2nd ed, Springer Verlag, 1988

3) Chesky VE, Hellwig CA, Welch JW : Fibrosarcoma of the thyroid gland. Surg Gynecol Obstet $111: 767-770,1960$

4) Aldinger KA, Naguib AS, Michael I, et al: Anaplastic carcinoma of the thyroid. Cancer 41: 2267-2275, 1978

5) Kind HP: Die Haufigkeit der struma maligna im sektions-und operationsgut des pathologischen instituts der universitat Zurich von 1900 bis mitte 1964. Schweiz Med Wochenochr 96 : $560-568,1966$
6) Hedinger $C E$ : Sarcomas of the thyroid. Arch Pathol 29: 541-552, 1940

7) Clive RT：免疫病理診断法. (养藤;偏監俢), 医学 書院サウンダース, 東京, 1987, p331-353

8) Kawahara $E$, Nakanishi I, Thrahata $S$, et al: Leiomyosarcoma of the thyroid gland. Cancer $62: 2558-2563,1988$

9）吉岡正和, 山本正之, 藤井秀樹他：甲状腺原発の平 滑筋肉連の 1 例，ホルモンと臨 $35 ： 145-147$, 1987

10) Louis MT, Berwick BL: Primary sarcoma of the thyroid gland. Ann Surg $26: 498-503,1897$

\title{
A CASE OF LEIOMYOSARCOMA OF THE THYROID GLAND SHOWING DEATH OUTCOME WITH RAPID COURSE
}

\author{
Yoshihiro KAWAGUCHI ${ }^{1}$, Masashi KANAZAWA' ${ }^{21}$, Koichi NAKAYAMA ${ }^{21}$, Kojiro URAZUMI ${ }^{2}$, \\ Shinichi TAKEUCHI ${ }^{2)}$ and Rikiya $\mathrm{ABE}^{2)}$ \\ 1) Department of Surgery, Takeda General Hospital \\ 2) The Second Department of Surgery, Fukushima Medical College \\ (Director: Prof. Rikiya ABE)
}

A 72-year-old woman, who was pointed out for a left thyroid tumor during her ambulatory treatment by ORL for dyspnea and cervical swelling, was referred to our departmetn. The patient underwent tracheotomy because of a rapid enlargement of the tumor and worsened dyspnea after admission, and at the same time a part of the tumor was resected for pathological examination. The H.E. stain suggested an anaplastic carcinoma, however, from findings in additional immunohistological stain, the nature of the tumor cells was finally confirmed as leiomyosarcoma. The patient died without any surgical treatment. Leiomyosarcoma of the thyroid gland is difficult to be differentiated from anaplastic carcinoma, especially spindle cell type, making immunohistological staining examinations indispensable. 